This item was submitted to Loughborough's Research Repository by the author.

Items in Figshare are protected by copyright, with all rights reserved, unless otherwise indicated.

\title{
Optimisation of the CZTSe thin film composition obtained by a sequential electrodeposition process
}

\section{PLEASE CITE THE PUBLISHED VERSION}

\section{PUBLISHER}

Taylor \& Francis on behalf of the Institute of Materials, Minerals and Mining

\section{VERSION}

AM (Accepted Manuscript)

\section{PUBLISHER STATEMENT}

This is an Accepted Manuscript of an article published by Taylor \& Francis in Surface Engineering on 12 July 2018, available online: http://www.tandfonline.com/10.1080/02670844.2018.1495415.

\section{LICENCE}

CC BY-NC-ND 4.0

\section{REPOSITORY RECORD}

Katirci, Ramazan, and Michael Walls. 2019. "Optimisation of the Cztse Thin Film Composition Obtained by a Sequential Electrodeposition Process". figshare. https://hdl.handle.net/2134/34104. 


\title{
Optimization of the CZTSe thin film composition obtained by a sequential electrodeposition process
}

Ramazan Katırc1*a,

E-mail: ramazan@asrelektrokimya.com.tr;

John Michael Walls ${ }^{\mathrm{b}}$,

E-mail: j.m.walls@1boro.ac.uk

\footnotetext{
a Istanbul Aydın University, Beşyol Mah.Inönü Cad.No: 38, Sefaköy-Küçükçekmece / İstanbul/Turkey ${ }^{\mathrm{b}}$ Centre for Renewable Energy Systems Technology, Wolfson School of Mechanical, Electrical and Manufacturing Engineering, Loughborough University, Leicestershire, LE11 3TU, U.K.
}

\begin{abstract}
The influence of the elemental composition of CuZnSn coatings deposited by electrodeposition on the formation of the $\mathrm{Cu}_{2} \mathrm{ZnSnSe}_{4}$ crystal structure following a selenization process was investigated using X-ray diffraction (XRD), scanning electron microscopy (SEM) and Raman spectroscopy. This study showed that the optimum alloy ratio to achieve the $\mathrm{Cu}_{2} \mathrm{ZnSnSe}_{4}$ crystal without impurity phases was in the range of $0.37-0.50$ for $\mathrm{Cu} /(\mathrm{Zn}+\mathrm{Sn})$ and $2.5-4$ for $\mathrm{Zn} / \mathrm{Sn}$.
\end{abstract}

Keywords: Kesterite $\left(\mathrm{Cu}_{2} \mathrm{ZnSnSe}_{4}\right)$ electroplating; Photovoltaic absorber; Thin film electrodeposition.

*Corresponding author: ramazan@asrelektrokimya.com.tr; Phone: +905353313748; Fax: +902122767966

Permanent address: Talatpasa Mah. Celebi Cad. Yanihan Sk: No:5; Okmeydani-Kagithane/Istanbul-TURKEY 


\section{Introduction}

Copper indium diselenide (CIS), and copper indium gallium diselenide (CIGS) thin films are widely used as the p-type absorber in photovoltaic devices. Thin film CIGS is an attractive photovoltaic absorber due to its high stability. However, CIGS absorbers contain expensive and rare elements such as 'In' and 'Ga', which limit their long-term sustainability for use in photovoltaic (PV) devices. Therefore, current research has been focused on replacing these rare elements with low-toxic and earth-abundant materials [1-3].

$\mathrm{Cu}_{2} \mathrm{ZnSn}(\mathrm{S}, \mathrm{Se})_{4}$ contains earth-abundant and low-toxic elements and is one of the most promising materials for the p-type absorber layer of thin film solar cells [4-5]. A number of studies on the fabrication of $\mathrm{Cu}_{2} \mathrm{ZnSn}(\mathrm{S}, \mathrm{Se})_{4}$ thin film solar cells have been reported [6]. Many coating methods have been used to deposit $\mathrm{Cu}_{2} \mathrm{ZnSnS}_{4}$ thin films. These include radio frequency (RF) magnetron sputtering [7], hybrid sputtering [8], thermal evaporation [9], photo-chemical coating [10], electroplating [11] spray pyrolysis [12], pulsed laser deposition [13], DC magnetron sputtering, etc. [14]. DC and RF magnetron sputtering deposition are the most common coating methods used for $\mathrm{Cu}_{2} \mathrm{ZnSnS}_{4}$ [15]. However, the high capital expenditure required to install a vacuum-based cell production line is a serious barrier to implementation. An atmospheric fabrication process would be much more financially attractive. Therefore, we use the electrodeposition method in this study. Previous studies of the electrodeposition of $\mathrm{Cu}_{2} \mathrm{ZnSnS}_{4}$ have examined the effects of process temperature, time, and medium during annealing after precursor deposition. [15-17].

Electroplating is comparatively cost-effective compared with other deposition methods due to its easy industrial implementation and low capital cost. Therefore, many $\mathrm{Cu}_{2} \mathrm{ZnSnSe}_{4}$ studies have been conducted using electrodeposition in recent years. This technique does not require high pressure, temperature or a vacuum environment and has a wide range of applications, including semi-conductor technology. $\mathrm{Cu}_{2} \mathrm{ZnSnSe}_{4}$ thin film has been electrodeposited using two approaches, sequential and co-deposition of metal layers [16,18]. Sequential metal 
deposition in separate electrochemical baths offers a convenient way to deposit each of the elements step by step. It also has the potential for precise control of the stoichiometry of the $\mathrm{Cu}_{2} \mathrm{ZnSnSe}_{4}$ film.

Changing composition systematically and studying its influence on the lattice of $\mathrm{Cu}_{2} \mathrm{ZnSnSe}_{4}$ solar cells has been carried out by Márquez et al. [19]. They obtained the $\mathrm{Cu}_{2} \mathrm{ZnSnSe}_{4}$ thin films using the sputtering method. Schurr et al. [17] investigated the effects of the crystal phases obtained before annealing on the structure of $\mathrm{Cu}_{2} \mathrm{ZnSnS}_{4}$. They showed that the phases formed prior to annealing, significantly affect the formation of $\mathrm{Cu}_{2} \mathrm{ZnSnS}_{4}$. The effects of elemental compositional changes on the $\mathrm{Cu}_{2} \mathrm{ZnSnSe}_{4}$ films obtained using the electroplating method and the formation of secondary phases have not been previously investigated. In this study, the effect of the composition changes systematically in the $\mathrm{CuZnSn}$ precursor films on the coating morphology and the crystal structure of the $\mathrm{Cu}_{2} \mathrm{ZnSnSe}_{4}$ was investigated. The changes in the composition of the $\mathrm{Cu}_{2} \mathrm{ZnSnSe}_{4}$ after annealing were monitored. In particular, the amount of $\mathrm{Sn}$ and $\mathrm{Zn}$ due to evaporation was observed.

\section{Experimental}

Mo deposited thin film on Soda-lime glass was used as the substrate. Prior to the electrodeposition, the substrates were cleaned with the cathodic electro-cleaning process for 5 minutes in the room temperature in alkaline solution $(\mathrm{pH}>10)$ using a current of $6 \mathrm{~A} / \mathrm{dm}^{2}$ and then rinsed under flowing deionised water. $\mathrm{Cu}, \mathrm{Zn}$ and $\mathrm{Sn}$ layers were sequentially electrodeposited on 5 x $5 \mathrm{~cm}$ substrates. Cu was electroplated in a bath containing $10 \mathrm{~g} / \mathrm{L}$ $\mathrm{CuSO}_{4} .5 \mathrm{H}_{2} \mathrm{O}$ and $100 \mathrm{~g} / \mathrm{L}$ pyrophosphate. $\mathrm{Zn}$ was electroplated in a bath consisting of $80 \mathrm{~g} / \mathrm{L}$ $\mathrm{ZnCl}_{2}$ and $150 \mathrm{~g} / \mathrm{L} \mathrm{NH}_{4} \mathrm{OH}$. Tin was electroplated in a bath including $10 \mathrm{~g} / \mathrm{L} \mathrm{SnSO}_{4}$ and 100 $\mathrm{g} / \mathrm{L}$ pyrophosphate. All platings were performed at room temperature using a current of 0.4 $\mathrm{A} / \mathrm{dm}^{2}$ and the $\mathrm{pH}$ 's of the baths were adjusted to $8.5,8.5$ and 4.5 respectively. The coating thickness before and after annealing was about 2 and $6 \mu \mathrm{m}$. Four samples with different composition were prepared and labelled from S1 to S4 (Table 2-4). The duration of 
electrodeposition of each sample was presented in Table 1. Sn electroplating for all samples was carried out for 5 minutes. In the next step, the annealing process was performed at 540 ${ }^{0} \mathrm{C}$ for 1 hour in a quartz tube in the presence of $0.6 \mathrm{~g}$ Se, under a nitrogen atmosphere whose pressure was $0.39 \mathrm{~atm}$. The annealing and the other processes were performed in the same way for all samples.

Table 1. The electrodeposition duration of $\mathrm{Cu}$ and $\mathrm{Zn}$ elements.

\begin{tabular}{ccc}
\hline Samples & $\begin{array}{c}\text { Cu } \\
(\text { min. })\end{array}$ & $\begin{array}{c}\text { Zn } \\
(\text { min. })\end{array}$ \\
\hline S1 & 6 & 12 \\
S2 & 12 & 6 \\
S3 & 12 & 12 \\
S4 & 6 & 6 \\
\hline
\end{tabular}

Table 2. Elemental percentage of $\mathrm{CZT}(\mathrm{CuZnSn})$ coating before annealing.

\begin{tabular}{|c|c|c|c|c|c|}
\hline Samples & $\begin{array}{c}\mathbf{C u} \\
/(\mathbf{C u}+\mathbf{Z n}+\mathbf{S n}) \\
\%\end{array}$ & $\begin{array}{c}\mathbf{Z n} \\
/(\mathbf{C u}+\mathbf{Z n}+\mathbf{S n}) \\
\%\end{array}$ & $\begin{array}{c}\mathbf{S n} \\
/(\mathbf{C u}+\mathbf{Z n}+\mathbf{S n}) \\
\%\end{array}$ & $\mathrm{Cu} /(\mathbf{Z n}+\mathbf{S n})$ & $\mathbf{Z n} / \mathbf{S n}$ \\
\hline S1 & 23 & 45 & 32 & 0.29 & 1.43 \\
\hline $\mathbf{S 2}$ & 43 & 24 & 33 & 0.75 & 0.71 \\
\hline S3 & 35 & 38 & 27 & 0.53 & 1.43 \\
\hline S4 & 29 & 29 & 41 & 0.42 & 0.71 \\
\hline
\end{tabular}

$\mathrm{Cu}, \mathrm{Sn}$ and $\mathrm{Zn}$ multilayer precursor films were electrodeposited using a Thurlby 30V-1A model direct-current generator. The annealing process was performed in the quartz furnace tube combined with a heater (Lenton). The structural properties of the annealed films were studied using XRD, Raman spectroscopy and SEM-EDS. XRD measurements were carried out at room temperature using a Bruker D2 Phaser model instrument, scanning between $30^{\circ}$ and $70^{\circ}$. The step width was set to 0.02 with 2 steps per second. Raman spectroscopy measurements (LabRam HR model) were performed using the $633 \mathrm{~nm}$ line of a HeNe laser 
$(50 \mathrm{~mW})$ as an excitation source. Scanning electron microscopy was carried out on a JEOL JSM-7800F High-resolution Analytical Field Emission Scanning Electron Microscope (FEGSEM). Energy dispersive X-ray spectroscopy (EDS) microanalysis was obtained using an Oxford Instruments X-max $80 \mathrm{~mm}^{2}$ detector, combined with Aztec software allowing standardless quantitative elemental analysis to be carried out.

\section{Results and discussion}

Table 2 and Table 3 show the elemental composition of the $\mathrm{CuZnSn}$ and $\mathrm{Cu}_{2} \mathrm{ZnSnSe}_{4}$ thin films before and after annealing respectively. The percentage of $\mathrm{Se}$ in the $\mathrm{Cu}_{2} \mathrm{ZnSnSe}{ }_{4}$ films is presented in Table 4. When comparing Table 2 and 3, Sn losses have been observed [8] due to evaporation during annealing. This causes the ratios of $\mathrm{Cu} /(\mathrm{Zn}+\mathrm{Sn})$ and $\mathrm{Zn} / \mathrm{Sn}$ to increase. Previous studies have concluded that the ideal ratios of $\mathrm{Cu} /(\mathrm{Zn}+\mathrm{Sn})$ and $\mathrm{Zn} / \mathrm{Sn}$ are $\sim 0.9$ and $\sim 1.25$ respectively [20-21]. In this study, we have changed the elemental composition in the CuZnSn films systematically (Table 3). The surface map was drawn to define the quality of the $\mathrm{Cu}_{2} \mathrm{ZnSnSe}{ }_{4}$ and secondary phase formations.

Table 3. Elemental ratios of CZTSe $(\mathrm{CuZnSnSe})$ coating after annealing.

\begin{tabular}{|c|c|c|c|c|c|}
\hline Samples & $\begin{array}{c}\mathbf{C u} \\
/(\mathbf{C u}+\mathbf{Z n}+\mathbf{S n}) \\
\%\end{array}$ & $\begin{array}{c}\mathbf{Z n} \\
/(\mathbf{C u}+\mathbf{Z n}+\mathbf{S n}) \\
\%\end{array}$ & $\begin{array}{c}\mathbf{S n} \\
/(\mathbf{C u}+\mathbf{Z n}+\mathbf{S n}) \\
\%\end{array}$ & $\mathrm{Cu} /(\mathbf{Z n}+\mathbf{S n})$ & $\mathrm{Zn} / \mathbf{S n}$ \\
\hline S1 & 33 & 58 & 9 & 0.50 & 6.72 \\
\hline S2 & 64 & 20 & 16 & 1.78 & 1.23 \\
\hline S3 & 50 & 38 & 12 & 1.00 & 3.22 \\
\hline S4 & 27 & 56 & 17 & 0.37 & 3.29 \\
\hline
\end{tabular}

Table 4. The alloy ratio of Se.

\begin{tabular}{lc}
\hline Samples & $\begin{array}{c}\text { Se } \\
\text { (wt. \%) }\end{array}$ \\
\hline S1 & 37.2 \\
S2 & 41.7 \\
S3 & 43.2 \\
S4 & 53.7 \\
\hline
\end{tabular}


Fig. 1 shows the surface morphology of $\mathrm{Cu}_{2} \mathrm{ZnSnSe}_{4}$ thin films. It was observed that the zincrich films, S1 and S4, have a smoother surface than the copper-rich films, S2 and S3. As seen in Fig 1, some defects are present on the surface of S3. These defects probably arise due to the hydrogen gas trapped while electroplating and is released after annealing. Copper-rich films have more secondary phases, which is probably caused by a high copper content because it forms the CuSe impurity phase. Consequently, $\mathrm{S} 4$ has the purest $\mathrm{Cu}_{2} \mathrm{ZnSnSe}_{4}$ structure, probably due to the high percentage of $\mathrm{Zn}$ and $\mathrm{Sn}$ in the film. Actually, the concentration of $\mathrm{Zn}$ in $\mathrm{S} 4$ is the same as $\mathrm{S} 1$, but $\mathrm{S} 4$ has much less impurity phases. Accordingly, the higher Sn concentration contained in S4 may be responsible for the decreased impurity phases.

\section{Fig 1.}

Fig 2 shows the XRD patterns and Raman scattering spectra of the $\mathrm{Cu}_{2} \mathrm{ZnSnSe}_{4}$ films. According to the XRD data, all samples exhibit CZTSe crystallinity. But the XRD data alone does not prove the existence of the $\mathrm{Cu}_{2} \mathrm{ZnSnSe}_{4}$ phase because the peaks of $\mathrm{ZnSe}$ and $\mathrm{Cu}_{2} \mathrm{SnSe}_{3}$ are very close to the peak of $\mathrm{Cu}_{2} \mathrm{ZnSnSe}_{4}$ [18]. Therefore, Raman spectra of these samples has been used to distinguish them. In the Raman spectra, the peaks at 172-173, 194197, 231-235 and 239-254 $\mathrm{cm}^{-1}$ confirm the presence of the $\mathrm{Cu}_{2} \mathrm{ZnSnSe}_{4}$ structure [22]. In our study, $\mathrm{XRD}$ patterns indicate that $\mathrm{S} 1$ and $\mathrm{S} 4$ have the purest $\mathrm{Cu}_{2} \mathrm{ZnSnSe}{ }_{4}$ crystals, but the Raman spectrums show that there are impurity phases in the S1 sample. It is difficult to distinguish the peaks of the ZnSe and CZTSe crystals via XRD spectrum because the appearance of the ZnSe and CZTSe peaks are very similar. Raman spectrum proves that the peaks at $\sim 250 \mathrm{~cm}^{-1}$ in the $\mathrm{S} 1$ sample result from a $\mathrm{ZnSe}$ structure in the film [22]. S4 has the best $\mathrm{Cu}_{2} \mathrm{ZnSnSe}_{4}$ crystallinity, as deduced from the Raman and XRD spectra. Impurity phases

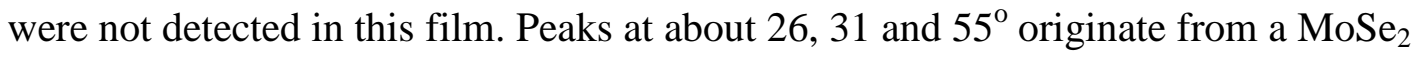

compound and were detected in all the samples. As seen in Table 3, the $\mathrm{Cu} /(\mathrm{Cu}+\mathrm{Zn}+\mathrm{Sn})$ and $\mathrm{Zn} /(\mathrm{Cu}+\mathrm{Zn}+\mathrm{Sn})$ ratios of the $\mathrm{S} 1$ and $\mathrm{S} 4$ samples are similar, but the $\mathrm{Sn}$ in $\mathrm{S} 4$ is higher than 
S1. This provides evidence that $\mathrm{Sn}$ enhances the crystallinity of the $\mathrm{Cu}_{2} \mathrm{ZnSnSe}_{4}$ and prevents the formation of secondary phases. Also, many impurity phases were observed in the XRD spectra from the $\mathrm{S} 2$ and $\mathrm{S} 3$ samples, in which the concentration of $\mathrm{Cu}$ is high, but the $\mathrm{Zn}$ is low. It is likely that the high $\mathrm{Cu}$ concentration increases the secondary phase concentration when the $\mathrm{Zn}$ concentration in the film is low.

Fig. 2.

Fig. 3 and Fig. 4 show the effect of the ratios of $\mathrm{Zn} / \mathrm{Sn}$ and $\mathrm{Cu} /(\mathrm{Zn}+\mathrm{Sn})$ to the intensity of $\mathrm{Cu}_{2} \mathrm{ZnSnSe}_{4}$ and impurity phase peaks. The intensities in Fig 3 give the total of the peak heights $(193,171,237)$ of the $\mathrm{Cu}_{2} \mathrm{ZnSnSe}_{4}$ and Fig 4 shows the total of the peak heights $(140$, 250) corresponding to impurity phases collected from Raman Scattering Spectra.

Fig. 3.

Fig. 4.

The maximum intensity in Fig. 3 a corresponds to the area of the best $\mathrm{Cu}_{2} \mathrm{ZnSnSe}_{4}$. This region is the dark green area in the contour plot (Fig. 3b). According to these plots, the ratios of $\mathrm{Cu}(\mathrm{Zn}+\mathrm{Sn})$ and $\mathrm{Zn} / \mathrm{Sn}$ should be maintained in the range of $0.37-0.50$ and 2.5-4 respectively. The formation of impurity phases in the $\mathrm{Cu}_{2} \mathrm{ZnSnSe}_{4}$ film affects the quality of the $\mathrm{Cu}_{2} \mathrm{ZnSnSe}_{4}$ crystal. Impurity phase formation should be restricted. In our work, the elemental ratios required to keep the impurity phases at a minimum level are presented in Fig. 4. It indicates that the ratio of $\mathrm{Cu} /(\mathrm{Zn}+\mathrm{Sn})$ should be below 0.5 and that the $\mathrm{Zn} / \mathrm{Sn}$ ratio should be in the range of 1.9-4.4. These ratio intervals are wider than the elemental ratios required to form the structure of $\mathrm{Cu}_{2} \mathrm{ZnSnSe}_{4}$ crystal. Hence, the elemental ratios used to obtain the maximum intensity of the $\mathrm{Cu}_{2} \mathrm{ZnSnSe}_{4}$ structure can also be used to restrict the formation of impurity phases. The dark green region in the contour plot in Fig. 4b shows the elemental ratios where the impurity phase density is the highest. It is important to ensure that the elemental ratios are outside these values. The elemental ratios in the coatings before and after annealing are different due to the evaporation of $\mathrm{Sn}$ at the annealing temperature. This 
makes the elemental ratios difficult to control. The evaporation amount of Sn depends on the elemental ratios and the structure as well as the annealing temperature [17].

\section{Conclusions}

In this study, the effect of the elemental ratios, prior to annealing, on the elemental ratios following annealing and the formation of the $\mathrm{Cu}_{2} \mathrm{ZnSnSe}_{4}$ crystal structure were investigated. Impurity phases formed during annealing were also investigated. The crystal purity of $\mathrm{Cu}_{2} \mathrm{ZnSnSe} \mathrm{H}_{4}$ in the $\mathrm{S} 4$ sample is maximum when the concentration of $\mathrm{Cu}$ in the coating is low, and $\mathrm{Zn}$ is high. When comparing $\mathrm{S} 1$ and $\mathrm{S} 4$, although the ratios of $\mathrm{Cu} /(\mathrm{Cu}+\mathrm{Zn}+\mathrm{Sn})$ and $\mathrm{Zn} /(\mathrm{Cu}+\mathrm{Zn}+\mathrm{Sn})$ are similar, it was observed that impurity phases were higher in the S1 sample. However, the concentration of $\mathrm{Sn}$ in $\mathrm{S} 4$ sample was higher than $\mathrm{S} 1$. Thus, Sn has a significant effect in preventing the formation of impurity phases. However, when S4 and S2 were examined together, the impurity phases in the $\mathrm{S} 2$ sample were too high, although the ratios of $\mathrm{Sn} /(\mathrm{Cu}+\mathrm{Zn}+\mathrm{Sn})$ in $\mathrm{S} 2$ and $\mathrm{S} 4$ samples were similar. This shows that $\mathrm{Sn}$ is not

sufficiently efficient by itself to prevent impurity phases. The concentrations of $\mathrm{Cu}$ and $\mathrm{Zn}$ are also very important.

In conclusion, in this study, the optimum elemental ratio to obtain the highest intensity of the $\mathrm{Cu}_{2} \mathrm{ZnSnSe}_{4}$ without impurity phases was determined to be in the range of $0.37-0.50$ for $\mathrm{Cu}(\mathrm{Zn}+\mathrm{Sn})$ and 2.5-4 for $\mathrm{Zn} / \mathrm{Sn}$ respectively, if the other conditions are maintained constant (such as annealing, etc.). At these ratio values, the formation of secondary phases was minimised.

\section{Acknowledgements}

We acknowledge the support of The Scientific and Technological Research Council of Turkey (TUBITAK) (Fellowship) and use of the facilities and the assistance of Keith Yendall in the Loughborough Materials Characterisation Centre.

\section{References}


[1] B. Ananthoju, F.J. Sonia, A. Kushwaha, D. Bahadur, N. V. Medhekar, M. Aslam, Improved structural and optical properties of $\mathrm{Cu} 2 \mathrm{ZnSnS} 4$ thin films via optimized potential in single bath electrodeposition, Electrochim. Acta. 137 (2014) 154-163. doi:10.1016/j.electacta.2014.05.166.

[2] C.P. Chan, H. Lam, C. Surya, Preparation of Cu2ZnSnS4 films by electrodeposition using ionic liquids, Sol. Energy Mater. Sol. Cells. 94 (2010) 207-211.

doi:10.1016/j.solmat.2009.09.003.

[3] K.V. Gurav, Y.K. Kim, S.W. Shin, M.P. Suryawanshi, N.L. Tarwal, U.V. Ghorpade, et al., Pulsed electrodeposition of $\mathrm{Cu} 2 \mathrm{ZnSnS} 4$ thin films: Effect of pulse potentials, Appl. Surf. Sci. 334 (2015) 192-196. doi:10.1016/j.apsusc.2014.09.079.

[4] E.M. Mkawi, K. Ibrahim, M.K.M. Ali, M. a. Farrukh, a. S. Mohamed, Influence of triangle wave pulse on the properties of $\mathrm{Cu} 2 \mathrm{ZnSnS} 4$ thin films prepared by single step electrodeposition, Sol. Energy Mater. Sol. Cells. 130 (2014) 91-98.

doi:10.1016/j.solmat.2014.06.039.

[5] H. Katagiri, K. Jimbo, S. Yamada, T. Kamimura, W.S. Maw, T. Fukano, et al., Enhanced conversion efficiencies of $\mathrm{Cu} 2 \mathrm{ZnSnS4}$-based thin film solar cells by using preferential etching technique, Appl. Phys. Express. 1 (2008) 0412011-0412012. doi:10.1143/APEX.1.041201.

[6] S. Delbos, Kësterite thin films for photovoltaics : a review, EPJ Photovoltaics. 3 (2012) 35004. doi:10.1051/epjpv/2012008.

[7] K. Jimbo, R. Kimura, T. Kamimura, S. Yamada, W.S. Maw, H. Araki, et al., $\mathrm{Cu} 2 \mathrm{ZnSnS} 4$-type thin film solar cells using abundant materials, Thin Solid Films. 515 (2007) 5997-5999. doi:10.1016/j.tsf.2006.12.103.

[8] T. Tanaka, T. Nagatomo, D. Kawasaki, M. Nishio, Q. Guo, A. Wakahara, et al., Preparation of $\mathrm{Cu} 2 \mathrm{ZnSnS} 4$ thin films by hybrid sputtering, J. Phys. Chem. Solids. 66 (2005) 1978-1981. doi:10.1016/j.jpcs.2005.09.037.

[9] K. Oishi, G. Saito, K. Ebina, M. Nagahashi, K. Jimbo, W.S. Maw, et al., Growth of $\mathrm{Cu} 2 \mathrm{ZnSnS} 4$ thin films on Si (100) substrates by multisource evaporation, Thin Solid Films. 517 (2008) 1449-1452. doi:10.1016/j.tsf.2008.09.056.

[10] K. Moriya, J. Watabe, K. Tanaka, H. Uchiki, Characterization of Cu2ZnSnS4 thin films prepared by photo-chemical deposition, Phys. Status Solidi. 3 (2006) 2848-2852. doi:10.1002/pssc.200669588.

[11] S.M. Pawar, B.S. Pawar, K. V Gurav, D.W. Bae, Fabrication of Cu2ZnSnS4 Thin Film Solar Cell Using Single Step Electrodeposition Method,Japanese Journal of Applied Physics. 51 (2012) 10NC27 doi.org/10.1143/JJAP.51.10NC27

[12] Y.B. Kishore Kumar, G. Suresh Babu, P. Uday Bhaskar, V. Sundara Raja, Preparation and characterization of spray-deposited $\mathrm{Cu} 2 \mathrm{ZnSnS} 4$ thin films, Sol. Energy Mater. Sol. Cells. 93 (2009) 1230-1237. doi:10.1016/j.solmat.2009.01.011. 
[13] K. Sekiguchi, K. Tanaka, K. Moriya, H. Uchiki, Epitaxial growth of Cu2ZnSnS4 thin films by pulsed laser deposition, Phys. Status Solidi. 3 (2006) 2618-2621.

doi:10.1002/pssc.200669603.

[14] F. Liu, Y. Li, K. Zhang, B. Wang, C. Yan, Y. Lai, et al., Solar Energy Materials \& Solar Cells In situ growth of $\mathrm{Cu} 2 \mathrm{ZnSnS} 4$ thin films by reactive magnetron cosputtering, 94 (2010) 2431-2434. doi:10.1016/j.solmat.2010.08.003.

[15] A. Emrani, P. Vasekar, C.R. Westgate, Effects of sulfurization temperature on CZTS thin film solar cell performances, Sol. Energy. 98 (2013) 335-340.

doi:10.1016/j.solener.2013.09.020.

[16] W. Septina, S. Ikeda, A. Kyoraiseki, T. Harada, M. Matsumura, Single-step electrodeposition of a microcrystalline $\mathrm{Cu} 2 \mathrm{ZnSnSe} 4$ thin film with a kesterite structure, Electrochim. Acta. 88 (2013) 436-442. doi:10.1016/j.electacta.2012.10.076.

[17] X. Zeng, K.F. Tai, T. Zhang, C.W.J. Ho, X. Chen, A. Huan, et al., Cu2ZnSn(S,Se)4 kesterite solar cell with $5.1 \%$ efficiency using spray pyrolysis of aqueous precursor solution followed by selenization, Sol. Energy Mater. Sol. Cells. 124 (2014) 55-60. doi:10.1016/j.solmat.2014.01.029.

[18] S. Ahmed, K.B. Reuter, O. Gunawan, L. Guo, L.T. Romankiw, H. Deligianni, A High Efficiency Electrodeposited Cu2ZnSnS4 Solar Cell, Adv. Energy Mater. 2 (2012) 253259. doi:10.1002/aenm.201100526

[19] J. Márquez, M. Neuschitzer, M. Dimitrievska, R. Gunder, S. Haass, M. Werner, et al., Systematic compositional changes and their influence on lattice and optoelectronic properties of Cu2ZnSnSe4 kesterite solar cells, Sol. Energy Mater. Sol. Cells. 144 (2016) 579-585. doi:10.1016/j.solmat.2015.10.004.

[20] W.C. Hsu, I. Repins, C. Beall, C. Dehart, G. Teeter, B. To, et al., The effect of Zn excess on kesterite solar cells, Sol. Energy Mater. Sol. Cells. 113 (2013) 160-164. doi:10.1016/j.solmat.2013.02.015.

[21] H. Katagiri, K. Jimbo, M. Tahara, H. Araki, K. Oishi, The Influence of the Composition Ratio on CZTS-based Thin Film Solar Cells, MRS Proc. 1165 (2009) 1165-M04-01. doi:10.1557/PROC-1165-M04-01.

[22] M. Meng, L. Wan, P. Zou, S. Miao, J. Xu, Cu2ZnSnSe4 thin films prepared by selenization of one-step electrochemically deposited $\mathrm{Cu}-\mathrm{Zn}$-Sn-Se precursors, Appl. Surf. Sci. 273 (2013) 613-616. doi:10.1016/j.apsusc.2013.02.088.

\section{Table Captions}

Table 1. The electrodeposition duration of $\mathrm{Cu}$ and $\mathrm{Zn}$ elements.

Table 2. Elemental alloys ratio of $\mathrm{CZT}(\mathrm{CuZnSn})$ coating before annealing.

Table 3. Elemental alloy ratios of CZTSe $(\mathrm{CuZnSnSe})$ coating after annealing. 
Table 4. The alloy ratio of Se.

\section{Figure Captions}

Fig. 1. SEM images of the surfaces of CZTSe films presented in Table 2

Fig. 2. XRD and Raman scattering spectra of the CZTSe film samples listed in Table 2.

Fig. 3. Surface (a) and contour plot (b) of the total intensity of CZTSe crystal structure peaks vs $\mathrm{Cu} /(\mathrm{Zn}+\mathrm{Sn}), \mathrm{Sn} / \mathrm{Sn}$.

Fig. 4. Surface (a) and contour plot (b) of the total intensity of secondary (impurity) phase peaks vs $\mathrm{Cu} /(\mathrm{Zn}+\mathrm{Sn}), \mathrm{Sn} / \mathrm{Sn}$. 